\author{
Aleksandra Vraneš \\ University of Belgrade \\ Faculty of Philology
}

УДК 008"20"

$316.7 " 20 "$

дОИ https://doi.org/10.18485/

melissa.2016.15.1.ch2

\title{
SHORT FOLK PROSE FORMS AS HEIRS OF CULTURAL AND ETHNIC HERITAGE OF MIGRANTS AND HOSTS
}

\begin{abstract}
Summary
Short prose forms, particularly folk proverbs and riddles, are heirs of the cultural and religious heritage of a nation. They carry within themselves beliefs, customs, rituals, entrenched attitudes, misconceptions, prejudices, common views on social phenomena, interpersonal relations, natural relations and their perceptions. They sometimes reveal more about a nation than the extensive ethnographic and historical studies, and at the same time, through the game and witticism, they may represent a form of education, cultural rapprochement and an elementary mastery of linguistic skills, important both for migrants and hosts. Do the short folk prose forms exist in virtual culture?
\end{abstract}

Key words: short prose forms; folk proverbs; folk riddles; culture of migrants; culture of hosts; cultural heritage; religious heritage, virtual culture.

Short prose forms, particularly folk proverbs and riddles, are heirs of the cultural and religious heritage of a nation. They carry within themselves beliefs, customs, rituals, entrenched attitudes, misconceptions, prejudices, common views on social phenomena, interpersonal relations, natural relations and their perceptions. They sometimes reveal more about a nation than the extensive ethnographic and historical studies, and at the same time, through the game and witticism, they may represent a form of education, cultural rapprochement and an elementary mastery of linguistic skills, important both for migrants and hosts.

In this unstable age, in which the reports on migrations are quite common in all media, traditional and virtual, and in which we all encounter migrants in the cities we live in, never before assuming that they can be faced with such challenges, in which human sufferings are rarely ac- 
companied by understanding, and even if they are, this understanding mostly implies material and physical support for survival. In this difficult and unstable age as well as in situations for which we are not prepared, we forget about the culture and education. At the same time, we constantly pride ourselves in living in the knowledge era. It seems as if there are two parallel realities. One in which we teach our children that it is necessary to educate themselves, to protect their own cultural and ethnic identity, and the other in which we do not recognize the importance of these values for those who are forced to leave their homes and go into the unknown, uncertain, not thinking that it is important to remember who they are and where they come from, as well as where they are and what are the people who receive or condemn them like. Their memory is in fact their identity. Serbian philosopher, Božidar Knežević, wrote that "Every theory, every principle represents only one thin thread drawn from the contexture of the overall process. Nevertheless, it is a whole thread. The longer the thread, the deeper and truer the theory gets (Knežević: 63)." The first insights into the culture of every individual are linked to the folk literature, mostly to short prose forms, fables, fairy tales, proverbs, riddles, conundrums. They are conveying folk wisdom on human character, temperament, nature of human relationships, the so-called general truths and life choices; they represent sparks of folk wittiness and shrewdness and guardians of local customs and rituals. We are often not aware of the fact that the buzzwords within serious discussions, representing a source of confirmation of our thesis, are actually more valid than scientific truths. Therefore, there is no reason to neglect their functionality when it comes to the need of overcoming and mutually understanding cultural differences, and at the same time establishing better understanding despite different ethnic, religious and cultural climate.

According to the UNHCR report from 2015, a total of 65.3 million people was displaced out of which 21.3 million were treated as refugees, whereby children below 18 years of age make up half of that population. Around 3.2 million people were waiting for the approval of their asylum application. In addition to Lebanon that hosted the largest number of refugees in relation to its population, Germany was the world's largest recipient of asylum applications with 441,900 of them registered during 
2015. The EU struggled to cope with the influx of over a million migrants crossing their borders, which resulted in creating division between EU countries. The UNHCR has recently reported that since the beginning of the current year 135,711 people have reached Europe by sea, the data that clearly indicate that the migrant crisis is not over. In order to respond to the crisis and enable somewhat easier assimilation of refugees in host countries, we must define and implement clear policies primarily in the field of education, but also in all other areas.

As a country located at the crossroads of Western and Eastern routes and winds, Serbia has temporarily or permanently accommodated, and it still does, a great number of migrants. By receiving them, Serbia, same as other countries, had to grasp international standards of protection in the field of migrations and asylum systems, and implement them within the national context throughout national legislative and regulatory framework. Acknowledging and understanding the phenomenon of migration and the sensitivity of the migrant population and gaining insight into the characteristics of the local systems' response to the regulations related to the exercise of migrants' rights, resulted in formulating the recommendations for improving the response to the needs of migrants and particularly vulnerable groups of migrants and their integration into the local communities. The migrants passing through Serbia mostly want to reach developed countries that have a more efficient asylum system. However, the number of asylum seekers is increasing year after year, and Serbia is becoming the desired destination. Therefore, the systematic and thorough assistance is needed, not only in terms of material, legal and health support, but also in terms of inclusion in the educational system and development of transculturality. The emphasis on transculturality reinforces sensitivity of both migrants and local population, enables higher level of cooperation, and hence greater efficiency in establishing communication that gradually leads towards achieving mutual trust. We believe that the distribution of educational materials, varying from one to several pages, in both Serbian and migrant languages would contribute to awakening their curiosity for the people to whom they merged; same as the education of the local population on migrants, their needs and culture would significantly contribute to a higher level of benevolent behavior, provided 
that we choose to ignore aggressive media communication. This would support the process of intercultural mediation, which would certainly result in intercultural understanding.

Interculturality is a process which is realized in permanent dialectics between unity and diversity, institutions and intuition, generality and particularity, memories and the future, beliefs and testimonies, meaningful responses and everyday demands, openness and closeness. Only a serious process of interculturalism, which takes account of all parts of the path one should cross, overcomes closeness and opens up the space for the search of such unity which is not benumbed by diversity. A superficial approach to interculturalism leads toward the loss of identity or absolutisation of a particular. Seeing that the identity is not given once and for all, but it is instead upgraded, changed, acquired and developed in contact with others, the transculturality thus represents the necessity of our time. The process of indicating and achieving a "human touch" and "human dimension" is based upon "human rights" and "human dignity", which can be found in the spiritual heritage of every nation rather than in its laws. This is the task for the serious educational system, but, at the same time, it represents the task for creative non-governmental organizations or alternative educational movements and projects. By publishing (in the traditional and virtual form) the works in which folk ingenuity and tradition is linked to the artistic expression, thus supporting intermediality; to the adequate linguistic base, available in the form of vocabulary and grammatical explanations; to graphic and linguistic lucidity, throughout brain teasers, mazes, crossword puzzles; by initiating mutual comparisons between the culture of refugees and the culture of recipients and through citing the stories, proverbs and witticisms with the same or similar meaning - we encourage, on the one hand, awareness and interest, and on the other, self-esteem of migrants, because we are not neglecting their need for educational and cultural contents. Thus, we are conveying the message to a marginalized social group that we want them to get to know the cultural context of the country in which they are currently residing, which, in an academic way, sends the message to the newcomers that we care to get to know them, despite their entirely non-academic and degrading conditions of living. This is quite enough for cultural optimism. 
Proverbs and riddles are the shortest, but also the richest literary form in spirit. Ethiopians believe that "a conversation without proverbs is like stew without salt", and Uzbeks claim that "the words of grandfathers are the source of wisdom". They encompass all the important areas of life and represent a significant testimony of the spiritual life of each nation, including our own. Proverbs contain the folk philosophy and omniscience. Concise and simple in form, they have condensed the thoughts and emotions into powerful images and molded linguistic expression into unusual jewels.

Cross-cultural comparisons are particularly important. The following proverbs are picturesque and are deeply grounded in the Arab culture:

"You reap what you sow."

"Money is a good servant but a bad master."

"The dog wags its tail, and a hypocrite his tongue."

"Better to take a poor wife than to fight with the rich one."

"If you want to get to know a woman's essence, look at the woman with eyes closed."

"Any man can make mistakes, but only an idiot persists in his error."

We can detect a parallel short prose form for each of them in every nation.

As cultural and educational institutions serving everyone, regardless of their race, gender, economic status and age, libraries are the best focal points of cultural curiosity, thus one expects their greater cultural engagement. Broekhof (2011) has conducted research and established that a child, who spends 15 minutes a day reading something, reads a million words during the entire year and enriches his vocabulary with 1,000 words. Sullivan and Brown (2013), who studied a national sample of 6,000 British nationals, have found that the vocabulary is developed with exactly the same success rate and efforts between the age of ten and sixteen. Other researchers (Krashen, 2013) have also found that reading for fun and relaxation has given better results in terms of developing the vocabu- 
lary of readers. Hence, the form of proverbs and riddles, which further develops creativity and imagination (Gille et al., 2010; OECD, 2011a), is highly desirable for acknowledging the habits and character of the new milieu.

With the help of librarians, the reader decides to move towards other literary forms as well, but his persistence and security in the process of reading socialization depends largely on his retention in the country in which he arrived. Of course, the manner in which the educational system of a certain country treats the refugees will also have a particular impetus. We are referring to the refugees fleeing from their country, but not from their own culture, which they love, respect and carry with them, whereby their host country provides them with an opportunity to present their culture and to familiarize themselves with the local one, in order to be able to assimilate properly and accept the new milieu. Once again we will cite the words of the Serbian philosopher of the early $20^{\text {th }}$ century: "The quest for a position in society is a tattoo of humaneness (Knežević: 88)." Today, humanity is tattooed in the virtual world.

\section{References:}

Кнежевић, Божидар (2002). Мисли. Прир. Александра Вранеш. Уб : Градска бибиблиотека „Божидар Кнежевић“.

Gil-Gonzalez, D., M.T. Ruiz-Cantero and C. Alvarez-Dardet (2009), "How political epidemiology research can address why the millennium development goals have not been achieved: Developing a research agenda", Journal of Epidemiology and Community Health, Vol. 63, Issue 4, April 2009, pp. 278-280.

Broekhof, K. (2011). Meer lezen, beter in taal. Effecten van lezen op taalontwikkeling [More reading, better in language. Effects of reading on language development]. Retrieved from http://www. siob.nl/media/documents/Meer-lezen-beter-in-taal3e-druk.pdf

Sullivan, A. and Brown, M. (2013) Social inequalities in cognitive scores at age 16: The role of reading. CLS Working Paper 2013/10. London: Centre for Longitudinal Studies. This paper has now been published as a journal article in the British Educational Review Journal.

Language Acquisition without Speaking and without Study. (Journal of Research of Bilingual Educaiton Research and Instruction 16(1): 215-221. 2014.) CHristy Lao and Stephen Krashen Posted: 2017-02-23 


\author{
Александра Вранеш \\ Универзитет у Београду \\ Филолошки факултет
}

\title{
КРАТКЕ НАРОДНЕ ПРОЗНЕ ФОРМЕ КАО БАШТИНИЦИ КУЛТУРНОГ И ЕТНИЧКОГ НАСЛЕЪА МИГРАНАТА И ДОМАЋИНА \\ Сажетак
}

Кратке прозне форме, нарочито народне пословице и загонетке, баштиници су културног и верског наслеђа једног народа. Оне носе собом веровања, обичаје, обреде, уврежена схватања, заблуде, предрасуде, уобичајене ставове о друштвеним појавама, међуљудским односима, природним релацијама и њиховом доживљавању. Они каткад о једном народу откривају више од обимних етнографских и историјских студија, а истовремено кроз игру и досетку могу да буду облик едукације, културног приближавања и елементарног овладавања лингвистичким вештинама, значајним како за мигранте, тако и за домаћине. Да ли кратке народне прозне форме постоје у виртуелној култури?

Кључне речи: кратке прозне форме; народне пословице; народне загонетке; култура миграната; култура домаћина; културно наслеђе; верско наслеђе, виртуелна култура. 